1.はじめた

\title{
○朴讯二郎者落久樹㸳木史人袴田真理子（弘前大） 锤田輝袷田勝高木明子永井政男
}

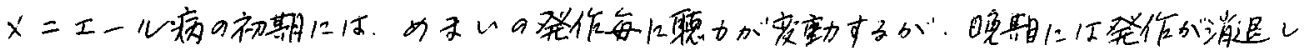

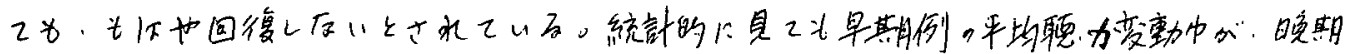

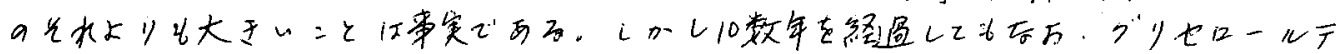

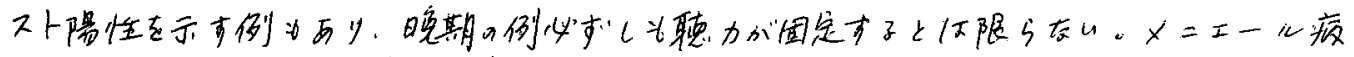

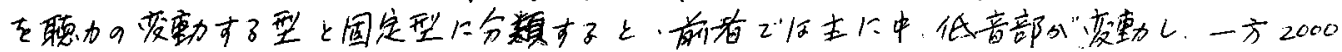
H区を界として高音部が低下国定し、所謂S型オージオグラムを示掦合が多いロに対し

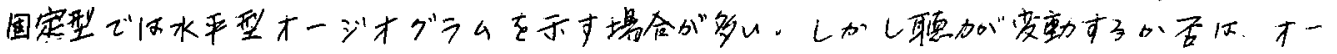

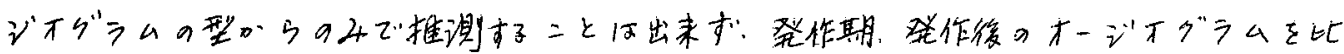

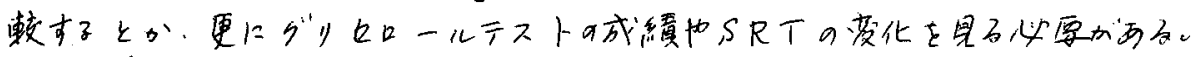

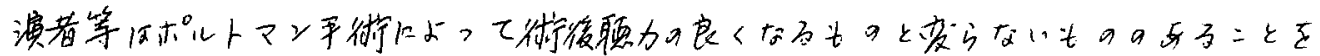

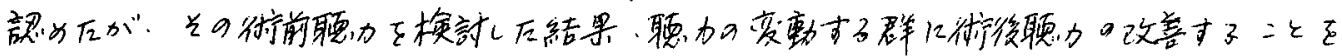

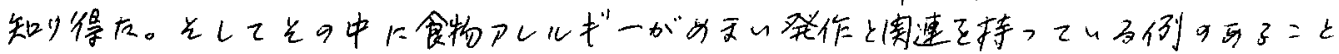

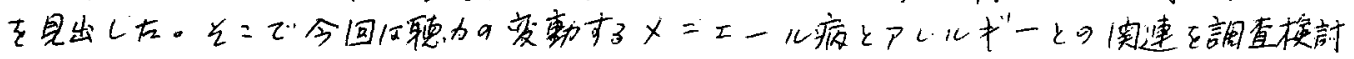
L $24 \pi$ 。

\section{2. 矮察对象方法万小代結果}

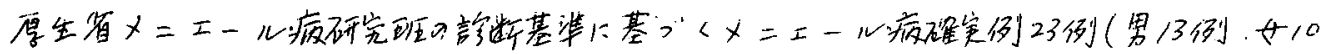

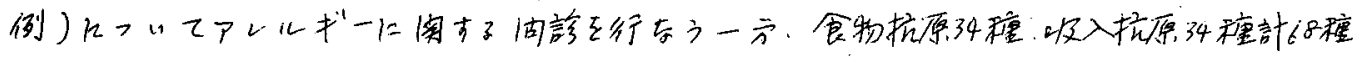

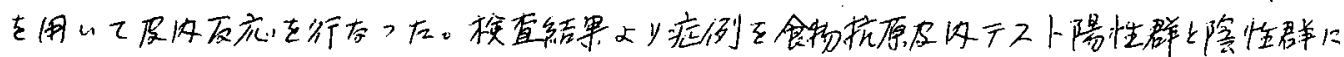

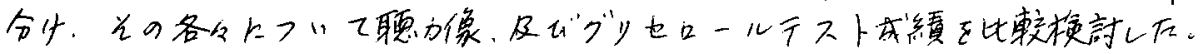

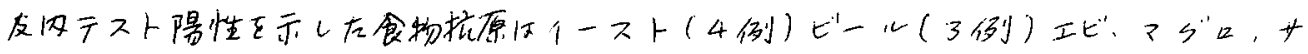

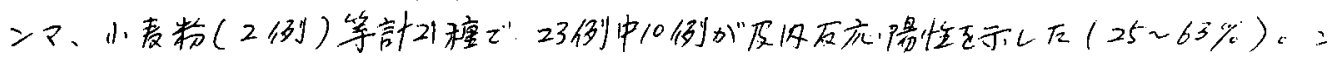

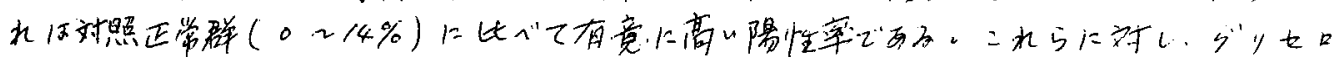

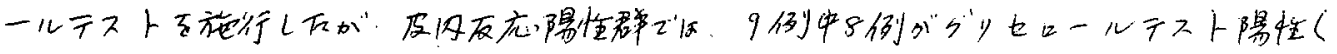

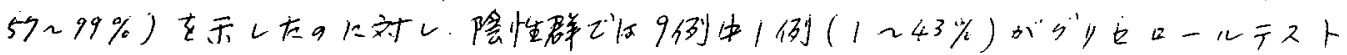

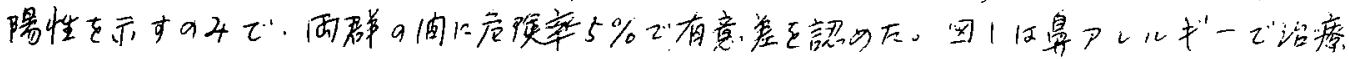

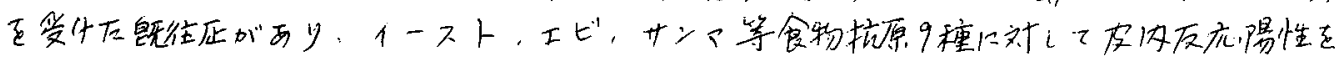

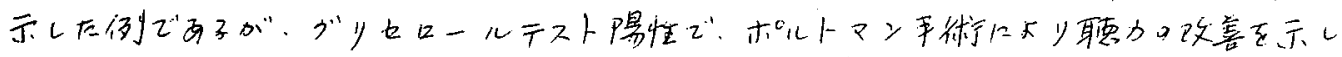

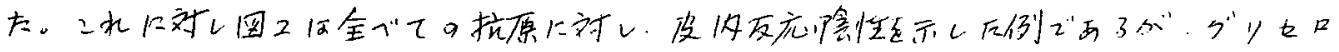

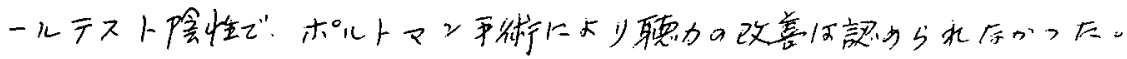

\section{3. 考按普じ結語}

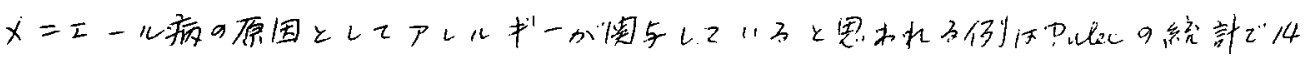

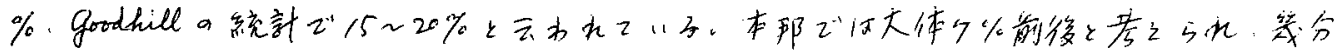

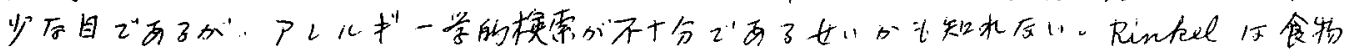

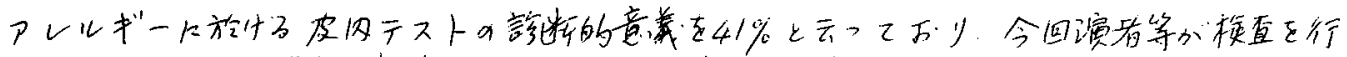

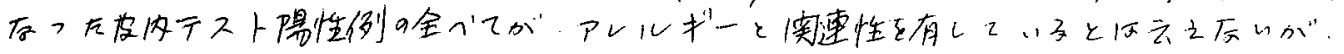


对照群に比してメ二=ーい病で皮 内下ス卜陽性率必高く。しか力淂 性群几䥺力宛動型が多”と云う二

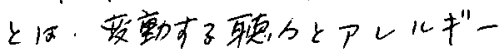

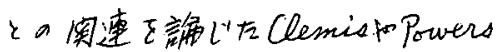
の報告々一致拓。

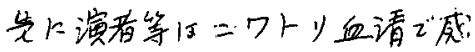
作し五鬼に左倒茎乳突孔上少拉原 tchallenge $L$ 专 $\varepsilon=3$, 左耳に内

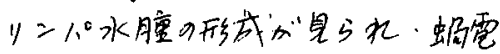
四に天少内栍婹力障害圭確認儿。 万。しかしと口後、長期鹳察例て

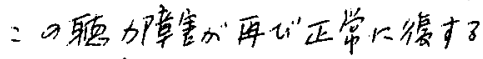
のを彩察し二いる(和了四)。二

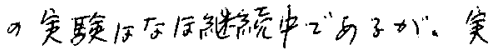

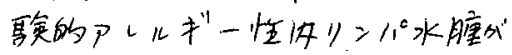

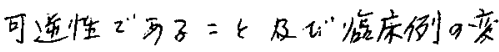
動才了婹力説明するヒントを提 示儿2い万㮇下思加及。

四1

皮内反応陽性例

32 才電エメニエール病

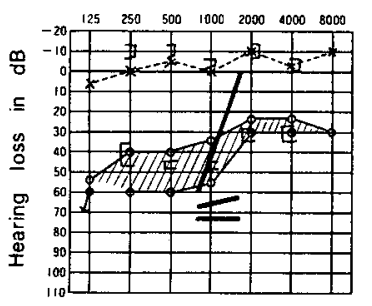

（初 発）昭和 50.12

（発作回数）1/月

(主症状)

右耳鳴、難聴の增

㰻を伴う回転性め まい

（治 療）昭和53.3

ポルトマン手術

(既往歴) 舜アレルギー

(皮内テスト)

陽性抗原

*斜線：グリセロール® $\oplus$ イースト $\frac{7 \times 7}{28 \times 22}$ $\left\langle\begin{array}{c}0 \\ 0 \\ 0\end{array} 0<\frac{11 \times 10}{39 \times 33}\right.$ 力丮(貝) $\frac{8 \times 8}{28 \times 27}$

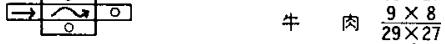

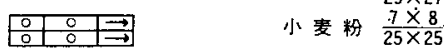
藏 $\quad$ サ $\frac{12 \times 10}{44 \times 35}$

Mann's test 正

Stepping test 正

D $\frac{11 \times 11}{33 \times 39}$

Caloric test $\mathrm{CP}($ 右 $)+\mathrm{DP}(\text { 左 })_{\text {カンシタ夕 }} \frac{9 \times 9}{9 \times 9}$

OKP

正常

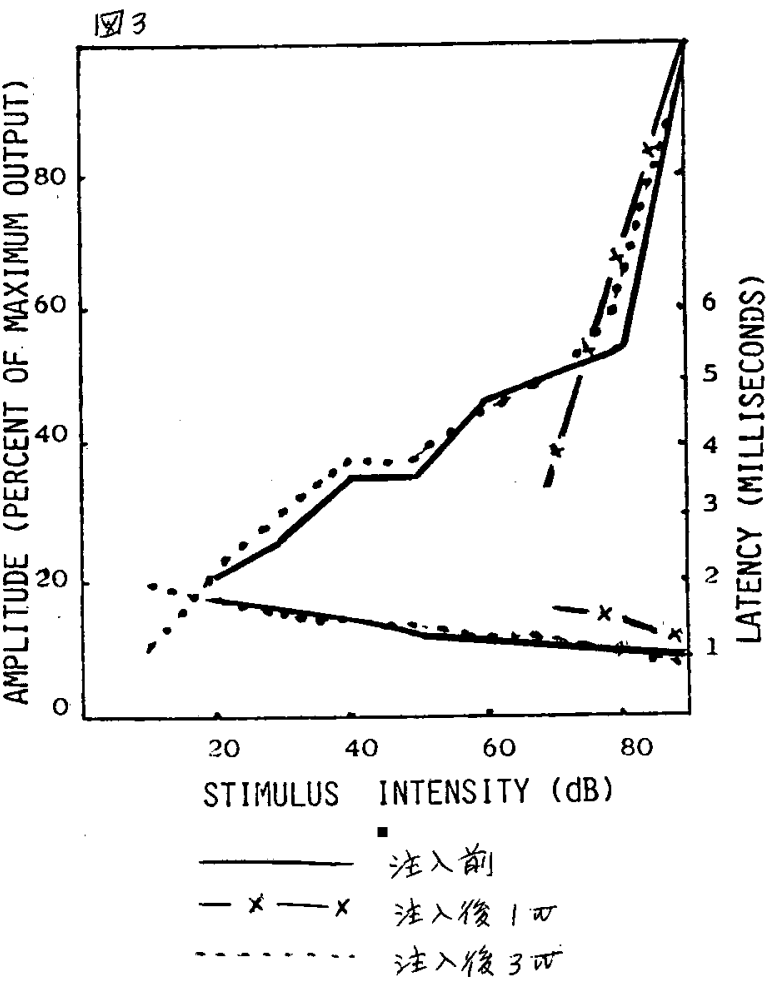

圆2 皮内反応陰性例

41才早 歯科技エ メニエール病

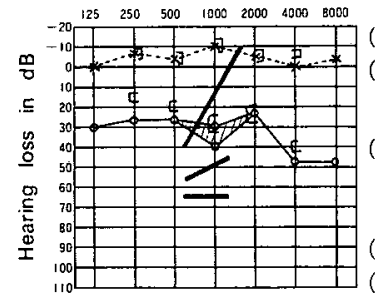

発) 昭和46年 秋

発作回数)

昭和51年まで $2 /$ 年

头の後頻回

(主症状)

右耳閉塞感，耳鳴

難㯖の增悪を伴う

回転性めまい

(既往歴) ピリン蒩疹

治癔) 昭和 53.5 .

グリセロール陰性（皮內テスト）

陽性抗原なし

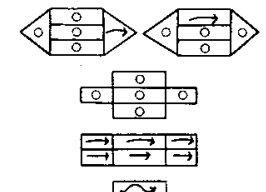

\begin{tabular}{ll}
\multicolumn{1}{c}{} & \multicolumn{1}{c}{$c$} \\
Mann's test & 正 \\
Stepping test & 正 \\
Cupulometry & 平行型 DP (左) \\
Caloric test & $C P$ (右) \\
OKP & 正常
\end{tabular}

